\title{
Using multivariate analysis to explore the relationships between color, composition, hygienic quality, and coagulation of milk from Manchega sheep
}

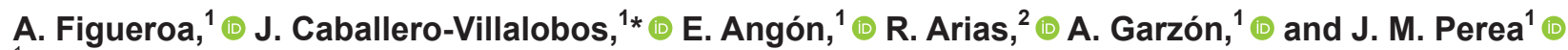 \\ ${ }^{1}$ Departamento de Producción Animal, Universidad de Córdoba, Córdoba 14071, Spain \\ ${ }^{2}$ Centro Regional de Selección y Reproducción Animal de Castilla-La Mancha, Valdepeñas, Ciudad Real 13300, Spain
}

\begin{abstract}
This study explores the relationships between composition, hygienic quality, and color values of milk to evaluate whether colorimetry could be used as a valid predictor of the quality of raw milk and its coagulation. For this purpose, we performed analyses in 1,200 individual samples of Manchega sheep milk from 4 flocks from the region of Castilla-La Mancha, Spain. Based on the measured variables, we determined the differences and similarities between coagulating and noncoagulating samples using discriminant analysis techniques. The variables with a higher discriminant ability were lactose content, somatic cell score, $\mathrm{pH}$, and the color values lightness $\left(\mathrm{L}^{*}\right)$ and red/green value $\left(\mathrm{a}^{*}\right)$. The model based on color values showed a predictive ability similar to that found in the model based on milk composition and hygienic quality. Canonical correlation analysis allowed us to explore the relationships between both sets of variables. Canonical correlations for the first and second pair of canonical values were 0.794 and 0.438 , respectively. Both values were significant and represented $92.82 \%$ of the observed variability. The correlation structure showed that color values had a strong correlation with fat and protein content and with total solids, and they had a weak correlation with lactose content and somatic cell score. The 2 first combinations of standardized canonical variability could be considered a predictable measure of the composition and, to a lesser extent, the hygiene of milk. Measurement of color values could be a rapid and effective means of supplementing standard analyses when determining the coagulation ability of Manchega sheep milk.
\end{abstract}

Received July 2, 2019.

Accepted February 3, 2020.

*Corresponding author: v22cavij@uco.es
Key words: sheep, multivariate analysis, colorimetry, milk coagulation

\section{INTRODUCTION}

Perception of color by the human eye is not exempt from subjectivity. For this reason, the International Commission on Illumination (CIE) has developed color space systems that can provide reliable information by measuring coordinates that can objectively represent human visual colors. For instance, the CIELAB color space (ISO/CIE, 2019) expresses color as 3 values: lightness $\left(\mathbf{L}^{*}\right)$, red/green value $\left(\mathbf{a}^{*}\right)$, and blue/yellow value $\left(\mathbf{b}^{*}\right)$. In addition, CIELCh (the cylindrical representation of the CIELAB system) combines lightness with 2 additional values to represent color: chroma or saturation $\left(\mathbf{C}^{*}\right)$ and hue $\left(\mathbf{h}^{*}\right)$. Traditionally, instrumental measurement of color using the CIELAB color space has been used to characterize the composition and quality of food products, and can be also used as an indicator of consumer preferences (Ramírez-Navas, 2010).

With respect to milk, most of the studies focused on colorimetry have aimed at the characterization of different types of cheeses during ripening (Álvarez et al., 2007; Ávila et al., 2017; Vargas-Uscategui et al., 2017) and the relationship between color and the fat content (Winkelman et al., 1999; McDermott et al., 2016) or hygienic quality (Espada et al., 2002) of bovine milk. Colorimetry studies of ewe milk are scarce; and very few references can be found in the literature. Jiménez Sobrino et al. (2018) analyzed raw material and the influence of different animal management practices on the composition and color of bulk tank milk, but they did not explore in depth the existing relationship between milk quality and color.

The importance of sheep milk production in Spain is unquestionable. In 2017, 510 million liters were produced, and $31 \%$ of this from the Manchega breed (Oviespaña, 2017). Milk from this breed is intended 
almost entirely for Protected Designation of Origin Manchego cheese (Arias et al., 2016). Production of this cheese is protected by the current regulations of the European Union, through which the marketing and export of a wide range of sheep milk products are acknowledged with quality marks such as Protected Destinations of Origin and Protected Geographical Indications (Cipolat-Gotet et al., 2016). To guarantee high standards for ewe milk, several factors must be considered, such as milk sanitary status, physicochemical quality, and technological performance. However, current methods for analyzing these parameters are slow and expensive, and they cannot be used to determine in situ milk coagulation capacity.

For this reason, we considered it a priority to develop a rapid, affordable, effective tool for predicting milk coagulation capacity. We hypothesized that the measurement of color values in milk could be a useful tool for quickly evaluating the technological capacity of milk from individual ewes, and also provide valuable information about its composition and sanitary status (Ramírez-Navas, 2010).

Previous studies support this hypothesis. GarcíaPérez et al. (2005) established that the $\mathrm{L}^{*}$ of milk depends mainly on the presence of colloidal particles (fat globules and casein micelles). Espada et al. (2002) reported that mastitis caused by Streptococcus esculin seemed to cause a yellowish-red coloring of milk, and that other changes in color were evident in cases of Streptococcus dysgalactiae udder infections. In addition, milk color values seem to be affected by factors such as herd nutrition. Faulkner et al. (2018) found that, in grazing herds with a diet based on grass or grass and clover, higher $\beta$-carotene induced changes in the perception of milk color, evidencing higher values of $\mathrm{b}^{*}$.

Considering these facts, we expected that color values could be used as quality benchmarks for milk and other dairy products. This study aimed to analyze the relationship between the composition, hygienic status, and colorimetry of milk to evaluate the possibility of developing predictive models based on color space systems and effectively estimate the quality of milk and its coagulation capacity in Manchega sheep.

\section{MATERIALS AND METHODS}

\section{Data Set and Collection of Milk Samples}

This study included the analysis of 1,200 individual milk samples from Manchega ewes from 4 farms in the region of Castilla-La Mancha, Spain (50 animals per flock). Milk was collected monthly during 2 different seasons (3 time points in spring and 3 more in autumn). Samples were collected during morning milking and stored at $4^{\circ} \mathrm{C}$ in hermetically sealed containers until analysis.

\section{Laboratory Analysis}

All analyses were performed in the Dairy Small Ruminant Laboratory (Departamento de Producción Animal, Universidad de Córdoba, Spain), within 5 h of sample collection. The native $\mathrm{pH}$ of the milk was measured using a Crison Basic20 pH meter (Crison Instruments S.A., Barcelona, Spain) and milk composition (fat, protein, lactose, and total solids) was determined by mid-infrared spectroscopy using a MilkoScan FT120 (Foss Electric, Hillerød, Denmark). Technological traits were monitored at $32^{\circ} \mathrm{C}$ using a Formagraph viscometer (Foss Electric), following the method first developed by McMahon and Brown (1982), with the modifications described by Caballero-Villalobos et al. (2018a). Briefly, this method is based on the oscillatory movement of pendula immersed in milk during coagulation. Coagulation was initiated by adding $50 \mu \mathrm{L}$ of a $4 \%$ single-strength liquid animal rennet solution to $10 \mathrm{~mL}$ of milk. The test was set up at $60 \mathrm{~min}$, and information was transferred to a computer and represented in a coagulation diagram including the following parameters: rennet clotting time, curd firming time, and curd firmness at 30 and $60 \mathrm{~min}$.

Somatic cell count was measured using a Fossomatic FC (Foss Electric). Then, a logarithmic transformation was applied to normalize the distribution (Ali and Shook, 1980), and the variable was expressed as SCS.

The color values of the milk were measured using the CIELAB color space and its cylindrical representation (CIELCh). Variables included $\mathrm{L}^{*}, \mathrm{a}^{*}$, and $\mathrm{b}^{*}$, which were measured using a PCE-CSM2 Color Meter (PCE Instruments Ltd., Southampton, UK) by placing the lens directly over a capsule containing the milk sample. Then, $\mathrm{C}^{*}$ and $\mathrm{h}^{*}$ were obtained using the formulas $\mathrm{C}^{*}$ $=\left(\mathrm{a}^{* 2}+\mathrm{b}^{* 2}\right)^{1 / 2}$ and $\mathrm{h}^{*}=\tan ^{-1}\left(\mathrm{~b}^{*} / \mathrm{a}^{*}\right)$ according to Daszkiewicz et al. (2012), and were also included as color variables.

\section{Statistical Analysis}

Preliminary testing of data was carried out to determine outliers to be discarded before further analysis. Pearson correlations were also analyzed to avoid variables that presented a correlation coefficient with an absolute value $>0.9$. Because data had different measurement units, they were standardized to zero mean and a unit standard deviation. The common descriptive characteristics of the studied variables are shown in Table 1. 
We used multivariate analysis techniques to analyze differences and similarities in color values, milk composition, and hygienic quality due to the coagulation process; and to evaluate the specific relationships between those factors. To discriminate between the 2 groups (coagulating/noncoagulating), we applied 3 complementary techniques: canonical discriminant analysis, stepwise discriminant analysis, and discriminant analysis.

Canonical discriminant analysis is a dimensionreduction technique related to principal component analysis and canonical correlation. Given a classification character and several variables, canonical discriminant analysis derives a set of new variables, called canonical functions, which are linear combinations of the original variables that summarize between-group variation in the data, highlighting their differences.

The minimum number of variables able to discriminate between the 2 groups was obtained performing stepwise discriminant analysis on 3 sets of variables: those related to milk composition and hygienic quality; those related to color; and those related to both sets of variables. The efficiency of the discriminant power of a given model was determined using the Wilks' $\lambda$ test of significance. We assessed the effective separation of groups using Mahalanobis distance and the corresponding Hotelling's $T^{2}$ test (De Maesschalck et al., 2000).

The most discriminant variables obtained in the stepwise discriminant analysis were selected and used for the canonical discriminant analysis and discriminant analysis. We tested the predictive ability of each model using the absolute assignment of samples to the preassigned group (Mardia et al., 2000).

The second step was to study the existing relationships between colorimetry and the quality traits of the milk. Canonical correlation analysis was deemed appropriate because it provides not only the magnitude of the

Table 1. Composition and color variables used to evaluate the coagulation process of Manchega sheep milk $(\mathrm{n}=920)$

\begin{tabular}{|c|c|c|c|}
\hline Variable & Unit/range & Mean & $\mathrm{SD}$ \\
\hline \multicolumn{4}{|l|}{ Composition } \\
\hline Fat content & $\%$ & 6.61 & 1.94 \\
\hline Protein content & $\%$ & 5.74 & 0.84 \\
\hline Lactose content & $\%$ & 4.88 & 0.40 \\
\hline TS & $\%$ & 18.13 & 2.47 \\
\hline SCS & $\log _{10}$ cells $/ \mathrm{mL}$ & 5.33 & 0.68 \\
\hline $\mathrm{pH}$ & $-\log \left[\mathrm{H}^{+}\right]$ & 6.64 & 0.29 \\
\hline \multicolumn{4}{|l|}{ Colorimetry $^{1}$} \\
\hline $\mathrm{L}^{*}$ & 0,100 & 82.86 & 1.81 \\
\hline$a^{*}$ & $-60,+60$ & -2.46 & 0.70 \\
\hline $\mathrm{b}^{*}$ & $-60,+60$ & 4.79 & 1.79 \\
\hline $\mathrm{C}^{*}$ & $\left(a^{*^{2}}+b^{* 2}\right)^{1 / 2}$ & 5.56 & 1.32 \\
\hline $\mathrm{h}^{*}$ & $\tan ^{-1}\left(\mathrm{~b}^{*} / \mathrm{a}^{*}\right)$ & -0.53 & 0.27 \\
\hline
\end{tabular}

${ }{ }^{*}=$ red/green value; $b^{*}=$ blue/yellow value; $C^{*}=$ chroma; $L^{*}=$ lightness; $h^{*}=$ hue. relationships that may exist between groups of variables but also a quantification of the relative contribution of each variable to those relationships (Tabachnick and Fidell, 1996). Canonical correlation analysis complements discriminant analysis, because the latter explores only associations between data without explaining why they exist (Caballero-Villalobos et al., 2018a).

Canonical correlation analysis is a multivariate analysis method based on the linear relationship between 2 multidimensional variables, $X$ and $Y$. The aim is to find linear combinations and so that the correlation between $U$ and $V$ is maximized. Such linear combinations reflect the relationship between both sets of variables (Yin, 2004). The basic principle of canonical correlation analysis is the construction of subsequent pairs of canonical variables $\left(U_{i}, V_{i}\right)$, that are linear combinations of the originals, so that each pair is orthogonal to the previous and represents the best explanation of the $Y$ set (formed by $q$ dependent variables) with respect to the $X$ set (formed by $p$ independent variables) that has not been obtained by the previous pairs (Liu et al., 2009). All statistical analyses were performed using SAS version 5 (SAS Institute Inc., Cary, NC).

\section{RESULTS AND DISCUSSION}

Table 2 shows the results of canonical discriminant analysis with the variables for milk composition and hygienic quality, colorimetry, and both sets of variables. The variables selected by stepwise discriminant analysis that better discriminated between coagulation/noncoagulation are noted in the table.

For milk composition and hygienic quality, the most discriminant variables were lactose, SCS, and $\mathrm{pH}$. Fat and protein content were also significant, but they showed lower discriminant power. For milk color values, the most discriminant variables were $\mathrm{L}^{*}, \mathrm{a}^{*}$, and $\mathrm{b}^{*}$. Considering both sets of variables together, those with a greater discriminant ability were lactose, SCS, pH, and $\mathrm{L}^{*}$.

Noncoagulating milk samples were characterized by a higher $\mathrm{pH}$, lower lactose content, higher fat and protein yields, and higher SCS. These results agreed with those obtained in milk from Sarda sheep by Pazzola et al. (2018): lactose, SCS, and pH affected milk composition and milk coagulation properties both simultaneously and also separately.

We applied canonical discriminant analysis to the selected variables for each of the 3 sets (Table 3 ). In all cases, the extracted canonical functions significantly discriminated between the 2 groups (coagulating/ noncoagulating; $P<0.0001$, Hotelling's $T^{2}$ test). The $F$-statistics revealed a higher discriminating ability for variables related to milk composition and hygienic 


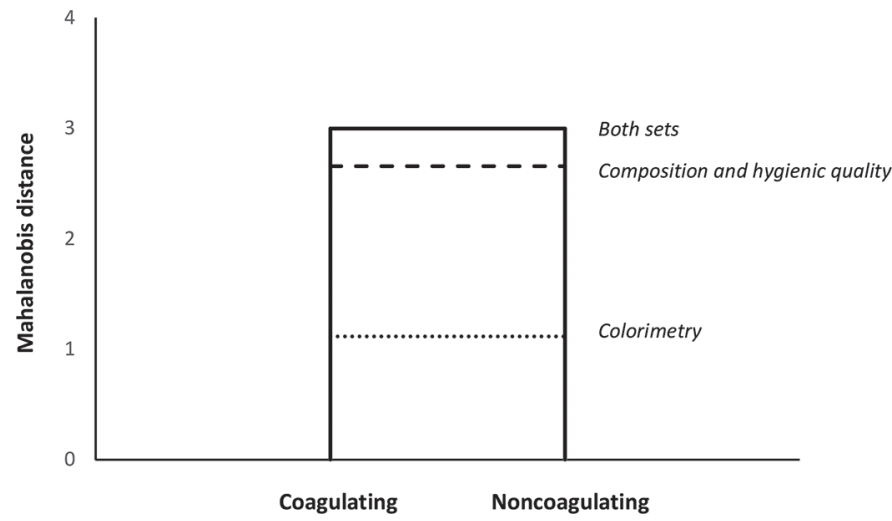

Figure 1. Dendrogram showing composition and colorimetry relationship between samples.

quality. This is also shown in Figure 1, which presents the values for Mahalanobis distance between both coagulation groups (1.116 for colorimetric variables, 2.657 for composition variables, and 2.998 for both sets). All pairwise distances were significant.

Discriminant analysis for the whole set of variables correctly classified $83.7 \%$ of the samples into their original groups (Table 4). The model based on composition and hygienic quality variables classified $82.4 \%$ of the samples correctly, and the model based on color variables correctly classified $76.3 \%$. The classification error for positive predictions was below $2.3 \%$ in all 3 models. For negative predictions, the classification error varied between $81.9 \%$ for model based on composition and hygienic quality, and $87.1 \%$ for the model based on color values.

The model based on color values showed a predictive ability similar to that of model based on milk composition and hygienic quality variables. These results indicated that the variation pattern of color variables reflected many of the changes in milk composition and hygienic quality that caused coagulation defects. Therefore, color values could be used as a potential indicator of deterioration of the coagulation process.

Results obtained from canonical correlation analysis are presented in Table 5. The model extracted $84.15 \%$ of the variance from the set of composition and hygienic quality variables, and $100.0 \%$ of the variance for the set of color variables. Canonical correlations for the first and second pair of canonical variables were 0.794 and 0.438 , respectively. These values were significant and represented $92.82 \%$ of the variability observed in the data.

The correlation structure in Figure 2 shows that color values were strongly correlated with fat and protein

Table 2. Results of canonical discriminant analysis with all variables measured for composition and hygienic quality, colorimetry, and both sets of variables

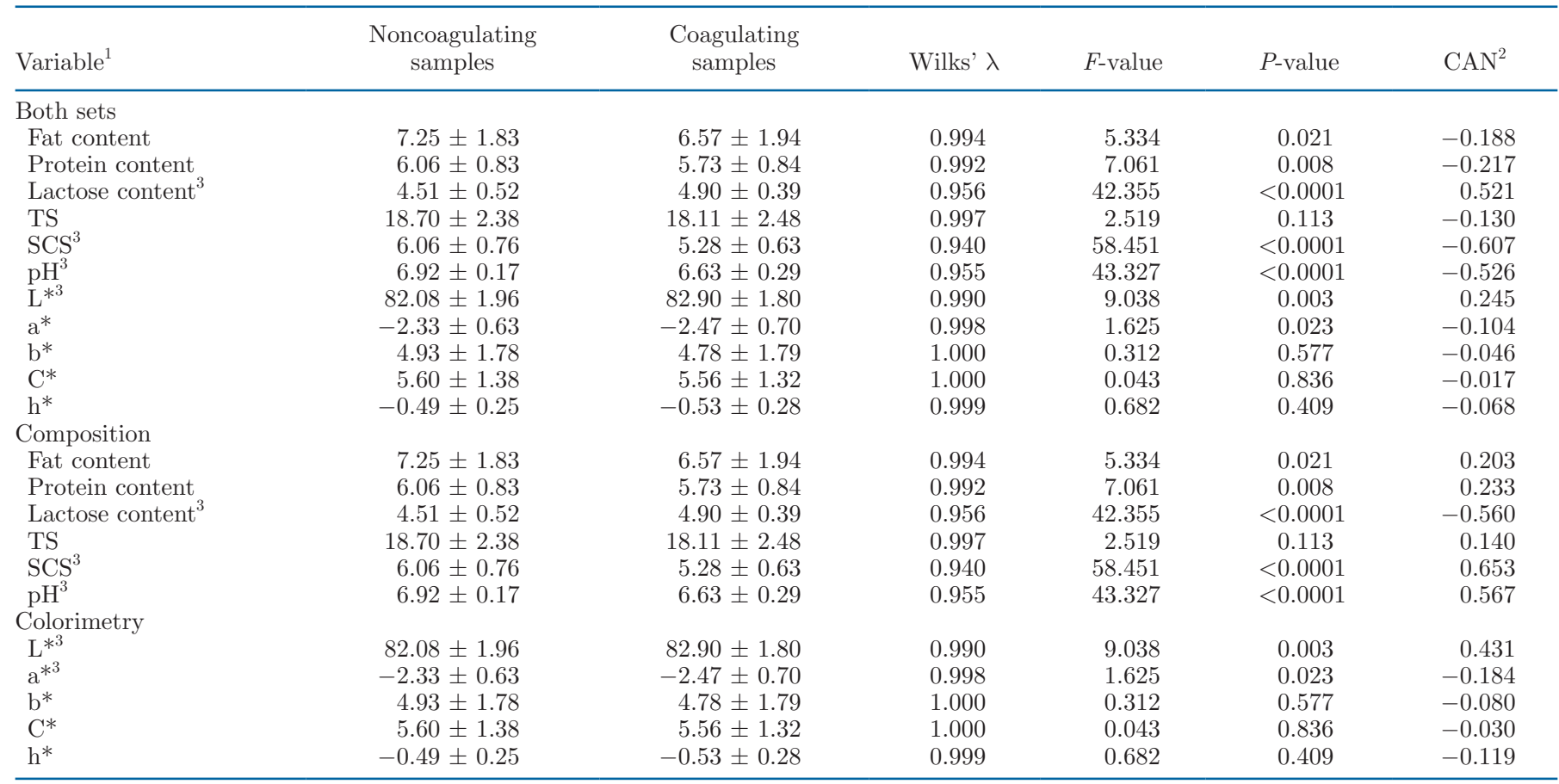

${ }^{1} \mathrm{a}^{*}=$ red/green value; $\mathrm{b}^{*}=$ blue/yellow value; $\mathrm{C}^{*}=$ chroma; $\mathrm{L}^{*}=$ lightness; $\mathrm{h}^{*}=$ hue.

${ }^{2} \mathrm{CAN}=$ correlation of each variable with the canonical function.

${ }^{3}$ Variables selected by the stepwise discriminant analyses. 
Table 3. Discriminant canonical models for composition variables, colorimetry, and both sets of variables ${ }^{1}$

\begin{tabular}{lllcl}
\hline Model & Variables in the model & $\begin{array}{l}\text { Number } \\
\text { of groups }\end{array}$ & Wilks' $\lambda$ & $F$-value \\
\hline Composition & Lactose, SCS, pH & 2 & 0.888 & $F(38,624)=2.615$ \\
Colorimetry & $\mathrm{L}^{*}, \mathrm{a}^{*}, \mathrm{~b}^{*}$ & 2 & 0.950 & $F(16,216)=2.615$ \\
Both sets & Lactose, SCS, pH, L* & 2 & 0.875 & $F(32,647)=2.382$ \\
\hline
\end{tabular}

${ }^{1} \mathrm{a}^{*}=$ red/green value; $\mathrm{b}^{*}=$ blue/yellow value; $\mathrm{L}^{*}=$ lightness.

content and total solids, and weakly correlated with SCS and lactose content. We observed no strong correlations with $\mathrm{pH}$. The first pair of canonical variables linked color variables and milk composition and showed a negative association between lactose content and fat and protein yields. The second pair of canonical variables linked color values to SCS and lactose content and showed a negative association between SCS and lactose. Thus, the first combination of standardized canonical variables could be considered a predictable measure of milk composition, and the second combination could be considered a predictable measure of milk hygienic properties.

One of the most important factors to affect milk coagulation is $\mathrm{pH}$, mainly because of its effect on the stability of casein micelles (Pirisi et al., 2007). Caballero-Villalobos et al. (2018b) reported that $\mathrm{pH}$ is the parameter that most conditions the efficiency of the coagulation process in Manchega ewe milk. Other studies have reported that coagulation time increases and coagulation properties worsen with an increase in the pH of milk (Bittante et al., 2017). The present study showed that noncoagulating milk samples were significantly differentiated by higher $\mathrm{pH}$ values, in agreement with previous investigations. Our results also indicated

Table 4. Assignation percentages in the predefined groups and classification errors

\begin{tabular}{lcc}
\hline Group & $\begin{array}{c}\text { Noncoagulating } \\
\text { samples }\end{array}$ & $\begin{array}{c}\text { Coagulating } \\
\text { samples }\end{array}$ \\
\hline Both sets & 63.04 & 36.96 \\
Noncoagulating samples & 15.22 & 84.78 \\
Coagulating samples & 0.82 & 0.02 \\
Level of error & 0.50 & 0.50 \\
Prior probability & & \\
Composition & 71.74 & 28.26 \\
Noncoagulating samples & 17.05 & 82.95 \\
Coagulating samples & 0.82 & 0.02 \\
Level of error & 0.50 & 0.50 \\
Prior probability & & \\
Colorimetry & 65.22 & 34.78 \\
Noncoagulating samples & 23.11 & 76.89 \\
Coagulating samples & 0.87 & 0.02 \\
Level of error & 0.50 & 0.50 \\
Prior probability & & \\
\hline
\end{tabular}

that variations in $\mathrm{pH}$ were not appropriately reflected by color variables.

Faulty coagulation of sheep and goat milk has been linked to higher SCC levels (Leitner et al., 2008; Caballero-Villalobos et al., 2018a) and has been attributed to the proteolytic effect of some enzymes (Poulsen et al., 2015). Several studies have demonstrated that high SCC levels delay the coagulation process and lead to deterioration in its properties (Maristela et al., 2015; Vacca et al., 2015; Pazzola et al., 2018). In agreement with these authors, the results of the present study showed that noncoagulating milk samples were differentiated by their higher SCS values. Furthermore, SCS and lactose content appeared to have a negative relationship. Such decreases in lactose content have been proposed as an indicator of udder health status (Vivar-Quintana et al., 2006; Manca et al., 2016).

Pazzola et al. (2018) suggested that the mechanism explaining the association between lactose and coagulation is related to the role of lactose as an osmotic regulator in milk (proven by Poulsen et al., 2015) and changes in the percentage and composition of minerals and proteins. Results from the present study were in agreement with those of Pazzola et al. (2018), who reported a worsening of coagulation properties in rela-

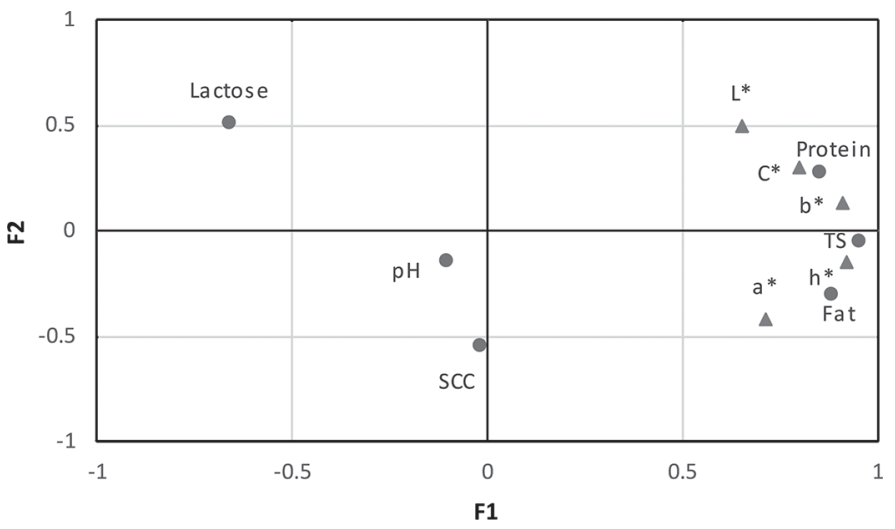

Figure 2. Correlation structure between the first 2 pairs of canonical variables (F1, F2) and the composition and hygienic quality (•) and colorimetry $\left(\boldsymbol{\Lambda} ; \mathrm{a}^{*}=\mathrm{red} /\right.$ green value; $\mathrm{b}^{*}=$ blue/yellow value; $\mathrm{C}^{*}$ $=$ chroma; $\mathrm{L}^{*}=$ lightness; $\mathrm{h}^{*}=$ hue) variables of milk. 
Figueroa et al.: QUALITIES OF MILK FROM MANCHEGA SHEEP

Table 5. Composition and color values obtained by canonical correlation analysis with all measured variables

\begin{tabular}{lcccrrr}
\hline Factor & Canonical correlation & Eigenvalue & Variability, $\%$ & Wilks' $\lambda$ & $F$-value & $P$-value \\
\hline $\mathrm{F}_{1}$ & 0.794 & 0.630 & 71.17 & 0.280 & 33.428 \\
$\mathrm{~F}_{2}$ & 0.438 & 0.192 & 21.65 & 0.758 & 8.559 \\
$\mathrm{~F}_{3}$ & 0.212 & 0.045 & 5.09 & 0.937 & $<0.000$ & $<0.000$ \\
\hline
\end{tabular}

tion to low lactose content, and a negative association between lactose and protein content.

According to De Marchi et al. (2013), the determination of milk chemical composition and coagulation properties requires the use of devices that are not suitable for quality control systems or for dairy plant cheese production lines because of the high cost of equipment, the need for highly qualified personnel, and the considerable investment of time. However, color variables can be measured quickly using portable, low-cost devices that do not require reagents or skilled staff. In other words, the model based on color parameters developed in the present study was able to predict faulty coagulation with the same precision as the model based on milk composition and hygienic quality, with less than $3 \%$ of the investment and no direct costs per milk sample.

For these reasons, colorimetry could be of great interest for the dairy sector. Color variables could provide a rapid and economical tool for analyzing Manchega milk and, according to the results obtained by Ferragina et al. (2017) using Fourier transform infrared spectroscopy, it would be possible to implement this model directly on samples collected during milk recording to gather a substantial amount of data from each animal. In addition, as reported by Winkelman et al. (1999) in a previous study performed on dairy cattle, milk color values seem to have a high heritability $(\approx$ 0.40 ), so color could be considered in selection schemes to improve major aspects of the dairy sheep industry.

\section{CONCLUSIONS}

The features that best differentiated the coagulation properties of Manchega sheep milk were SCS, pH, and lactose content. However, color values had similar predictive ability, and could be used as a potential indicator of coagulation ability. Color values in Manchega milk were strongly correlated with fat content, protein content, and total solids, and they were also slightly correlated with SCS and lactose content. Colorimetry could offer a predictable measure of milk composition, although it provides less information about hygienic quality. The measurement of color values in milk could be a rapid and effective means of supplementing standard analyses when determining the coagulation ability of Manchega sheep milk.

\section{ACKNOWLEDGMENTS}

The authors acknowledge the Spanish Association of Manchega Sheep Breeders (AGRAMA) for their assistance with this study. The authors declare that there are no conflicts of interest regarding the publication of this paper.

\section{REFERENCES}

Ali, A. K. A., and G. E. Shook. 1980. An optimum transformation for somatic cell concentration in milk. J. Dairy Sci. 63:487-490. https: //doi.org/10.3168/jds.S0022-0302(80)82959-6.

Álvarez, S., V. Rodríguez, M. E. Ruiz, and M. Fresno. 2007. Correlaciones de textura y color instrumental con la composición química de quesos de cabra canarios. Arch. Zootec. 56:663-666.

Arias, R., R. Gallego, S. Altares, A. Garzón, J. Romero, L. Jiménez, B. Oliete, C. Arias, J. Caballero, A. Martínez, N. Núñez, A. García, M. Ramón, V. Montoro, and M. Pérez-Guzmán. 2016. Quality of milk in Manchego sheep flocks. A review. Arch. Zootec. 65:469-473.

Ávila, M., N. Gómez-Torres, D. Delgado, P. Gaya, and S. Garde. 2017. Effect of high-pressure treatments on proteolysis, volatile compounds, texture, colour, and sensory characteristics of semi-hard raw ewe milk cheese. Food Res. Int. 100:595-602. https://doi.org/ 10.1016/j.foodres.2017.07.043.

Bittante, G., C. Cipolat-Gotet, M. Pazzola, M. L. Dettori, G. M. Vacca, and A. Cecchinato. 2017. Genetic analysis of coagulation properties, curd firming modeling, milk yield, composition, and acidity in Sarda dairy sheep. J. Dairy Sci. 100:385-394. https://doi.org/ 10.3168/jds.2016-11212.

Caballero-Villalobos, J., A. Figueroa, K. Xibrraku, E. Angón, J. M. Perea, and A. Garzón. 2018a. Multivariate analysis of the milk coagulation process in ovine breeds from Spain. J. Dairy Sci. 101:10733-10742. https://doi.org/10.3168/jds.2018-14752.

Caballero-Villalobos, J., J. M. Perea, E. Angón, R. Arias, and A. Garzón. 2018b. Coagulation efficiency and its determinant factors: A case study for Manchega ewe milk in the region of Castilla-La Mancha, Spain. J. Dairy Sci. 101:3878-3886. https://doi.org/10 $.3168 /$ jds.2017-13816.

Cipolat-Gotet, C., A. Cecchinato, M. Pazzola, M. L. Dettori, G. Bittante, and G. M. Vacca. 2016. Potential influence of herd and animal factors on the yield of cheese and recovery of components from Sarda sheep milk, as determined by a laboratory bench-top model cheese-making. Int. Dairy J. 63:8-17. https://doi.org/10 .1016/j.idairyj.2016.07.013.

Daszkiewicz, T., D. Kubiak, R. Winarski, and M. Koba-Kowalczyk. 2012. The effect of gender on the quality of roe deer (Capreolus capreolus L.) meat. Small Rumin. Res. 103:169-175. https://doi .org/10.1016/j.smallrumres.2011.09.044.

De Maesschalck, R., D. Jouan-Rimbaud, and D. L. Massart. 2000. The Mahalanobis distance. Chemom. Intell. Lab. Syst. 50:1-18. https: //doi.org/10.1016/S0169-7439(99)00047-7.

De Marchi, M., V. Toffanin, M. Cassandro, and M. Penasa. 2013. Prediction of coagulating and noncoagulating milk samples Using mid-infrared spectroscopy. J. Dairy Sci. 96:4707-4715. https://doi . org/10.3168/jds.2012-6506.

Espada, E., H. Vijverberg, and N. V. Maasland. 2002. Milk color analysis as a tool for the detection of abnormal milk. Pages $28-38$ in 
Proc. First North Am. Conf. on Robotic Milking, Toronto, Canada. Wageningen Pers, Wageningen, the Netherlands.

Faulkner, H., T. F. O'Callaghan, S. McAuliffe, D. Hennessy, C. Stanton, M. G. O'Sullivan, J. P. Kerry, and K. N. Kilcawley. 2018. Effect of different forage types on the volatile and sensory properties of bovine milk. J. Dairy Sci. 101:1034-1047. https://doi.org/10 $.3168 /$ jds.2017-13141.

Ferragina, A., C. Cipolat-Gotet, A. Cecchinato, M. Pazzola, M. L. Dettori, G. M. Vacca, and G. Bittante. 2017. Prediction and repeatability of milk coagulation properties and curd-firming modeling parameters of ovine milk using Fourier-transform infrared spectroscopy and Bayesian models. J. Dairy Sci. 100:3526-3538. https://doi.org/10.3168/jds.2016-12226.

García-Pérez, F. J., Y. Lario, J. Fernández-López, E. Sayas, J. A. Pérez-Alvarez, and E. Sendra. 2005. Effect of orange fiber addition on yogurt color during fermentation and cold storage. Color Res. Appl. 30:457-463. https://doi.org/10.1002/col.20158.

ISO/CIE. 2019. Colorimetry-Part 4: CIE 1976 L*a*b* colour space. 11664-4:2019. International Organization for Standardization, Geneva, Switzerland; Commission internationale de l'éclairage, Vienna, Austria.

Jiménez Sobrino, L., J. M. Poveda Colado, A. I. Garzón Sigler, A. L. Martínez Marín, N. Núñez Sánchez, J. R. Asensio, M. D. PérezGuzmán Palomares, and R. Arias Sánchez. 2018. Composition and colour indices of sheep's bulk-tank milk are influenced by production practices. Ital. J. Anim. Sci. 17:477-488. https://doi.org/10 $.1080 / 1828051 X .2017 .1383860$.

Leitner, G., N. Silanikove, and U. Merin. 2008. Estimate of milk and curd yield loss of sheep and goats with intrammamary infection and its relation to somatic cell count. Small Rumin. Res. 74:221225. https://doi.org/10.1016/j.smallrumres.2007.02.009.

Liu, J., W. Drane, X. Liu, and T. Wu. 2009. Examination of the relationships between environmental exposures to volatile organic compounds and biochemical liver tests: Application of canonical correlation analysis. Environ. Res. 109:193-199. https://doi.org/ 10.1016/j.envres.2008.11.002.

Manca, M. G., J. Serdino, G. Gaspa, P. Urgeghe, I. Ibba, M. Contu, P. Fresi, and N. P. P. Macciotta. 2016. Derivation of multivariate indices of milk composition, coagulation properties, and individual cheese yield in dairy sheep. J. Dairy Sci. 99:4547-4557. https://doi .org/10.3168/jds.2015-10589.

Mardia, K. V., F. L. Bookstein, and I. J. Moreton. 2000. Statistical assessment of bilateral symmetry of shapes. Biometrika 87:285-300. https://doi.org/10.1093/biomet/87.2.285.

Maristela, R., R. Natalia, C. Gerardo, S. Jordi, and L. Gabriel. 2015. Effect of subclinical intramammary infection on milk quality in dairy sheep: I. Fresh-soft cheese produced from milk of uninfected and infected glands and from their blends. Small Rumin. Res. 125:127-136. https://doi.org/10.1016/j.smallrumres.2015.02.019.

McDermott, A., G. Visentin, S. McParland, D. P. Berry, M. A. Fenelon, and M. De Marchi. 2016. Effectiveness of mid-infrared spectroscopy to predict the color of bovine milk and the relationship between milk color and traditional milk quality traits. J. Dairy Sci. 99:3267-3273. https://doi.org/10.3168/jds.2015-10424.

McMahon, D. J., and R. J. Brown. 1982. Evaluation of formagraph for comparing rennet solutions. J. Dairy Sci. 65:1639-1642. https:// doi.org/10.3168/jds.S0022-0302(82)82390-4.
Oviespaña. 2017. Castilla-La Mancha produjo durante el pasado año 158 millones de litros de leche de oveja el 31 de los 510 millones de litros que se generaron en España. Accessed May 11, 2017. https://www.oviespana.com/informacion-de-ovino/servicio -diario-de-noticias/noticias/castilla-la-mancha-produjo-durante-el -pasado-ano-158-millones-de-litros-de-leche-de-oveja-el-31-de-los -510-millones-de-litros-que-se-generaron-en-espana.

Pazzola, M., C. Cipolat-Gotet, G. Bittante, A. Cecchinato, M. L. Dettori, and G. M. Vacca. 2018. Phenotypic and genetic relationships between indicators of the mammary gland health status and milk composition, coagulation, and curd firming in dairy sheep. J. Dairy Sci. 101:3164-3175. https://doi.org/10.3168/jds.2017-13975.

Pirisi, A., A. Lauret, and J. P. Dubeuf. 2007. Basic and incentive payments for goat and sheep milk in relation to quality. Small Rumin. Res. 68:167-178. https://doi.org/10.1016/j.smallrumres 2006.09.009.

Poulsen, N. A., A. J. Buitenhuis, and L. B. Larsen. 2015. Phenotypic and genetic associations of milk traits with milk coagulation properties. J. Dairy Sci. 98:2079-2087. https://doi.org/10.3168/ jds.2014-7944.

Ramírez-Navas, J. S. 2010. Espectrocolorimetría en caracterización de leche y quesos. Tecnol. Láctea Latinoam. 61:52-58.

Tabachnick, B. G., and L. S. Fidell. 1996. Using Multivariate Statistics. 3rd ed. Harper Collins, New York, NY.

Vacca, G. M., M. Pazzola, M. L. Dettori, E. Pira, F. Malchiodi, C. Cipolat-Gotet, A. Cecchinato, and G. Bittante. 2015. Modeling of coagulation, curd firming, and syneresis of milk from Sarda ewes. J. Dairy Sci. 98:2245-2259. https://doi.org/10.3168/jds.2014 -8902 .

Vargas-Uscategui, R., A. Arenas-Clavijo, and J. S. Ramírez-Navas. 2017. Efecto del proceso de acidificación sobre el color de queso cottage. Agron. Mesoam. 28:677-690. https://doi.org/10.15517/ ma.v28i3.22876.

Vivar-Quintana, A. M., E. Beneitez De La Mano, and I. Revilla. 2006. Relationship between somatic cell counts and the properties of yoghurt made from ewes' milk. Int. Dairy J. 16:262-267. https:// doi.org/10.1016/j.idairyj.2005.03.006.

Winkelman, A. M., D. L. Johnson, and A. K. H. MacGibbon. 1999. Estimation of heritabilities and correlations associated with milk color traits. J. Dairy Sci. 82:215-224. https://doi.org/10.3168/jds .S0022-0302(99)75226-4.

Yin, X. 2004. Canonical correlation analysis based on information theory. J. Multivariate Anal. 91:161-176. https://doi.org/10.1016/ S0047-259X(03)00129-5.

\section{ORCIDS}

A. Figueroa (1) https://orcid.org/0000-0003-2758-6112

J. Caballero-Villalobos @ https://orcid.org/0000-0003-1432-9109

E. Angón (i https://orcid.org/0000-0002-6807-6146

R. Arias ๑ https://orcid.org/0000-0001-8608-8274

A. Garzón ๑ https://orcid.org/0000-0002-0543-5164

J. M. Perea ๑ https://orcid.org/0000-0002-7496-6794 